\title{
The Importance of Being Political: Emergence of a Multi-stakeholder Forum at the Lake Malili Complex, South Sulawesi
}

\author{
Nurhady Sirimorok ${ }^{1, *}$ and Eko Rusdianto ${ }^{1}$ \\ 1 Peasant School Network of PAYO-PAYO. Maros, South Sulawesi, Indonesia. \\ * Corresponding author: nurhadys@gmail.com
}

\begin{abstract}
Multi-stakeholder forums are considered an essential element of landscape approaches for sustainable development and integrated ecosystem management. Such forums are widely adopted in environmental management policies and are introduced as precursors for institutional arrangements. The implementation of such initiatives however, are usually slow, high in transaction costs, often become dysfunctional or turn into a formality. Indeed, rather than achieving greater inclusion and representation, some arrangements can further marginalize weaker participants. In this respect, the importance of politics in shaping the success of a multi-stakeholder forum is often overlooked. This article examines the different multi-stakeholder mechanisms applied in managing the Lake Malili Complex in Sulawesi, Indonesia. The case highlights a successful bottom-up multi-stakeholder approach that became a model for collaboration, and which was subsequently scaled up to cover the broader Lake Malili Complex area. The Lake Malili Complex is a set of 5 connected lakes in South Sulawesi with many different interests contesting its uses. It is a critical resource for surrounding communities, large industries in the region, and is also home to threatened endemic species. The research is based on longstanding participation in the politics of decision-making processes at the Lake Malili Complex, complemented by in-depth examination of the establishment of the multi-stakeholder forum. The findings show that strong, locally-based initiatives provide an avenue for generating greater participation in achieving mutual goals for conserving the Lake Malili Complex. However, participation in the multi-stakeholder platform is not enough to push for decision making at the district level, where more powerful management decisions take place. We therefore note that outcomes of communitybased resource management are limited when they are not backed by more political approaches to affect decision making powers in order to better manage conflicting land use aspirations and practices within the Complex.
\end{abstract}

Keywords: Lake Malili Complex; multi-stakeholder platform; land use; conservation

\section{Introduction}

Multi-stakeholder forums have long been introduced as an essential component of integrative landscape approaches for sustainable development and integrated ecosystem management, and have been adopted in various policies and institutional arrangements (Lee, 1994). Such forums can help to provide an avenue for different parties to meet and make decisions on various objectives concerning land use within a certain landscape; and by doing so minimizes the trade-off between development, livelihoods, and natural resource conservation (Estrada-Carmona et. al., 2014; Sayer et. al., 2015; Kuster et al., 2018; Sarmiento Barletti and Larson, 2019). Multi-stakeholder platforms also provide the potential linkages for forming bottom-up alternatives for land use management, as opposed to the more commonly accepted paradigms of top-down approaches (Reed, 2010).

However, the implementation of multi-stakeholder initiatives for integrative land uses are normally slow, create high transaction costs, often experience turbulence and can become dysfunctional over time, and furthermore, may also further marginalize weaker groups of participants (Garcia-Lopez, 2013; Kuster et al., 2018). In this respect the importance of politics is often overlooked. The failure of multi-stakeholder forums for instance, are regularly interpreted as stemming from the lack of "coordination" among the parties involved, as participating actors are assumed to be equal in terms of power (Kohne, 2014; Ravikumar et al., 2018; Sarmiento Barletti and 
Larson, 2019). The asymmetries of power are often overlooked. For example, analyzing an Indonesian case of state forest management units (Kesatuan Pengelola Hutan, or KPH) through multi-stakeholder governance, Riggs et al. (2018) found that the initiative often encountered narrow sectoral interests (what they described as "egosektoral"), and which subsequently led to a lack of integration and legitimation among stakeholders. This case highlights the power struggles among stakeholders from state agencies contesting their role and claim to resources, and also point to the top-down nature of decision making within the state agency responsible for the multistakeholder forum (Sahide and Giessen, 2015).

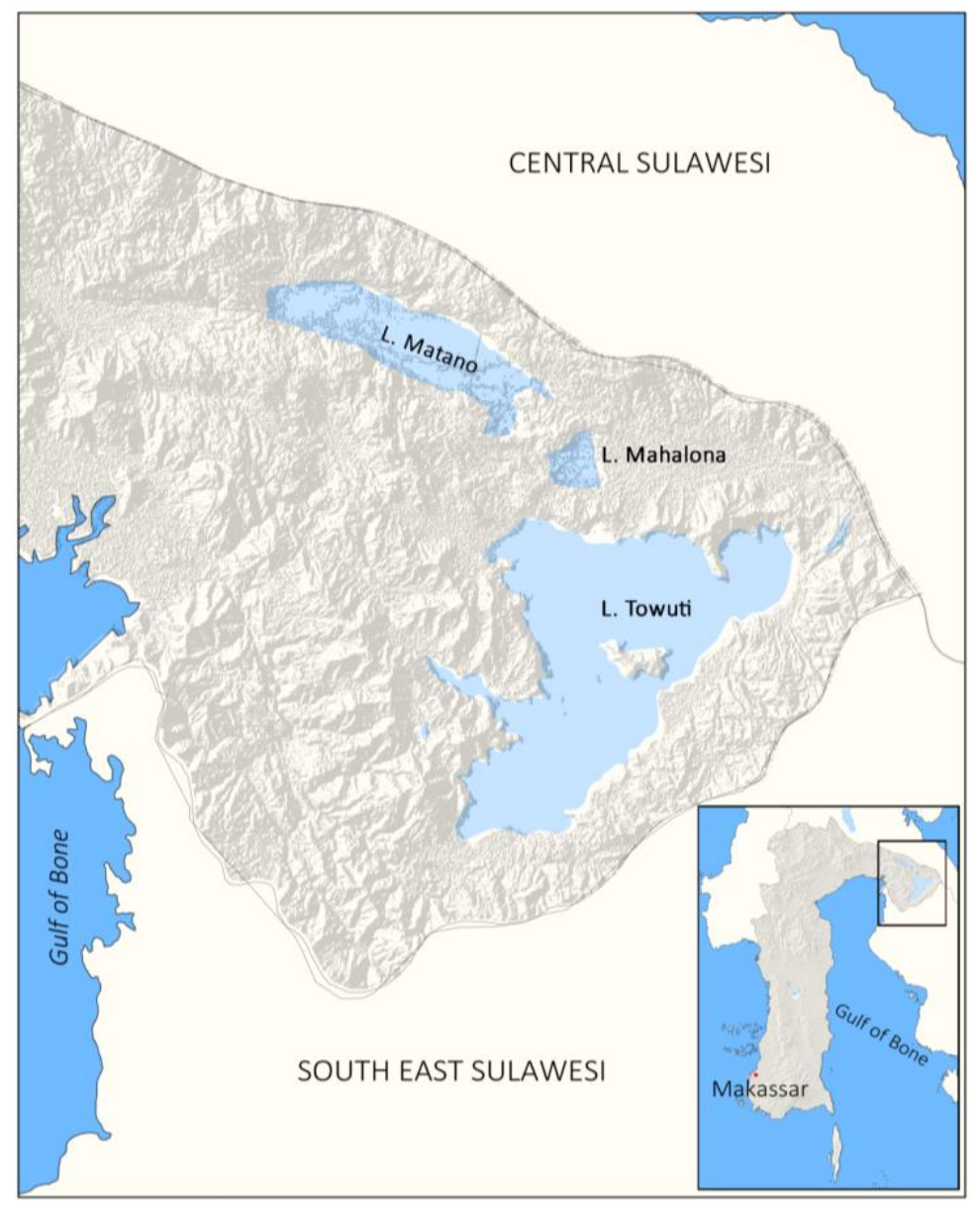

Figure 1. Malili Lake Complex

This study examined a multi-stakeholder forum that applied integrated landscape approach principles in Indonesia. Our study focuses on a landscape known as The Lake Malili Complex (hereafter, the Complex, see MAP 1). The Complex, that among others, comprises of three large lakes has gained national and international attention for the increasing pressure from various interest groups on managing the natural resources of the lakes and their surrounding landscapes. One of the most influence is PT Vale, which is one of the largest nickel mining operations in the world. PT Vale at once depends on the lake for water access, and also has the rights to keep the water at a certain level to ensure the continuous power generation of hydro-electric dams. ${ }^{1}$

\footnotetext{
${ }^{1}$ The power generated amounts to $365 \mathrm{MW}$ from the three dams combined and supply the entire mining operation. The company also grants $10,7 \mathrm{MW}$ of the total generated power to the district government, who in turn sells it to the stateowned electric company for their distribution (Palopopos 2019).
} 
Meanwhile, communities living near the lakes depend on them for clean water, use for small industries (sawmill and pepper rinsing), fishing and hunting areas, freshwater fish breeding (karamba), as well as other important agriculture activities tied to lake access. However, in some areas, people living on stilted houses on the banks of the lake also create a buildup of sedimentation and waste that has not been properly managed, particularly at the southern parts of Lake Matano, and more intensive pepper rinsing industries at part of Lake Mahalona. ${ }^{2}$

Aside from PT Vale, and local community interest, a third cluster of groups can be described as falling into the conservationist category. These conservationists have identified numerous endemic and threatened species for protection, and actively lobby formal institutions managing natural resources to fulfill their mandates on the environment. The Ecosystem Profile: Wallacea Biodiversity Hotspot, compiled by a global collaboration of environmental organizations labeled the Complex as a 'Key Biodiversity Area,' stating that the region contains "a population of globally threatened species, globally significant population of an endemic species or a species that is highly dependent on conservation of the sites." (Langhammer et al. in Burung Indonesia-CEPF, 2014: 23-24). The concerns over the 'critical' or 'threatened' status of the lakes within the Complex have mobilized conservation groups at different scales, including groups forming at the district and provincial levels, as well as interventions from national and international organizations. In addition, National Geographic (November 2008) penned a special report about Lake Matano, describing the lake as the sixth deepest in the world. At 585 meters depth, it also creates a unique condition of lakes called a crypto-depression lake (i.e. a lake that extends deeper than sea level).

In the face of these overlapping interests, multi-stakeholder approaches have been applied to manage the Lake Complex as a unified landscape. These initiatives come from different organizations with interests of serving conservation and development objectives, and also come to the table in pursuit of different outcomes. These initiatives follow in the global trend of conservation management practices around sustainable and equitable development and conservation towards decentralized or polycentric governance efforts, which are presumed to require multi-stakeholder platforms for involving diverse types of knowledge and objectives (Ostrom 2010; Kusters et. al., 2017; Ravikumar et al., 2018; Sarmiento Barletti and Larson, 2019).

This paper presents a case study that examines how multi-stakeholder initiatives have been applied to manage various conservation and development efforts at the Complex. Though various studies have examined the process of multi-stakeholder forums we specifically sought to examine the role of politics in multi-stakeholder forums. Our approach thus involved a comparison of multistakeholder ccollaboration platforms at different scales, ones that apply top-down models of governance, with ones that emerge from below. We examine their broader rationales for engagement and points of departure, contrasting various institutional arrangements to understand the nature of participation and legitimation, as well as the relationships among and between the participants. We also present the way the various platforms evolved over time and the key decisions that underpin their successes and continued active participation. By doing so, we point to the key role of politics in the viability of a multi-stakeholder collaboration platform to stay relevant and enact change among conservation and development interests.

\section{Methodology}

\subsection{The Setting: Lake Malili Complex}

The Complex is located in East Luwu District, at the northeastern tip of the Province of South Sulawesi, around 600 kilometers from the provincial capital, bordering Central and South East Sulawesi Province. It comprises of three large lakes: Matano (16.408 ha), Mahalona (2.440 ha), and

\footnotetext{
2 Interview with community member; member of (NGO working with the community); Head of District Land Use and Housing Plan; observation.)
} 
Towuti ( $56.108 \mathrm{ha}$ ), each with different elevation that enable the highest one, Matano ( $382 \mathrm{~m}$ above sea level) to supply water to the lower ones, Mahalona (310 masl), Towuti ( 280 masl). The water from Towuti then flows to a large River, Larona, that flows into the Gulf of Bone.

To the south of Lake Matano and Mahalona are mine concessions, the plant site, offices and the housing complex of PT Vale employees, as well as the town of 'Sorowako' (name for the area under administrative jurisdiction of Sorowako, Nikkel, and Magani Villages). To the south of Lake Matano, the residents almost exclusively depend on PT Vale. Besides working for the company, they also work for hundreds of contractors competing to gain contracts from PT Vale and the diverse services supporting them. Meanwhile, areas to the south of Lake Towuti include another series of villages, mining concessions, and agricultural land. Overall, the southern areas of the Lake Complex are dominated by settlements and mining operations, while areas to the west, north, and east of the Complex consist mostly of protected forests that overlap with farmlands and sprawling settlements. The Complex is also home to dozens of endemic fishes and other aquatic species such as buttini (Glossogobius matanensis) and opudi (Thelmaterina), threatened bird such as elang Sulawesi (Spizaetus lanceolatus) and maleo (Macrochepalon maleo); and terrestrial species such as anoa (Babalus quarlesi) dan babirusa (Babyrousa babyroussa), as well as endemic trees such as dama' dere (Vatica rassak), mata kucing (Hopea celebica), rode (Vatica flavovirens/celebica), and betao kuning (Calophyllum soulattri) (National Geographic 2008; Burung Indonesia-CEPF 2014).

Government agencies responsible for natural resource management are also active throughout the Complex. These include district and village governments, the Natural Resource Conservation Agency (BKSDA), River Basin Management Agency (BPDAS), and the Larona Forest Management Office (KPH). Among the area surrounding the lakes and its water catchment area, these agencies operate with overlapping formal authorities. The state protected forest area (hutan lindung) for example, is under the authority of the $\mathrm{KPH}$, but is located within the protected area administered by BPDAS and BKSDA, which are also responsible for river basin area management and the Natural Reserve areas (Cagar Alam), respectively. Meanwhile, within the same protected forest are dozens of villages with homes and farms that existed long before the establishment of protected areas by the state. These areas are still administered under village governments, which gained renewed authority in 2014 under the Village Law (UU Desa). ${ }^{3}$ The lake is thus parceled under the various administrative area authority of surrounding villages, with their own rule-making and development planning processes based on the Village Law. The lakes are also concurrently designated as an ecotourism park area (Taman Wisata Alam), and thus falls under the management authority of BKSDA. However, the large water volume from the lakes are managed by the mining company (PT Vale) in order to provide constant water supply for the company's three hydro-electric dams along the Larona river outlet. The power generated from the dams total 365 megawatts. 4 These numerous and overlapping mandates and interests highlight a messy, complex, and fragmented set of management conditions across the landscape, which overwhelm the political problem of landscape management (Sahide and Giessen 2015; Meyers et. al. 2018). As a result, various technical coordination initiatives have been proposed, which we examine in the empirical sections of this paper.

\footnotetext{
${ }^{3}$ One weakness of the Village Law is that the villages cannot overrule other formal authority overlapping their jurisdiction. Therefore, if the land and forest within a village located under jurisdiction of Ministry of Environment and Forestry or situated at a mining company concession, another Law is required to return them to community authority (Shohibuddin et. al. 2017).

${ }^{4}$ The three hydropower dams (PLTA), from upstream to downstream, are as follows: PLTA Larona (generates 165 megawatts), Balambano (110 mws) and Karebbe (90 mws) (http://www.vale.com/indonesia/bh/business/energy/ourhydro-power-plant-in-indonesia/pages/default.aspx).
} 


\subsection{The study of multi-stekaholder platforms}

Studies of multi-stakeholder platforms emerged from a wide range of fields, from integrative governance (Ravikumar et al., 2018), natural resource management (Reed et al. 2009), political ecology (Sarmiento Barletti and Larson, 2019), as well as institutional analysis and development (Ostrom 2010), to integrated landscape initiatives (Sayer et. al., 2014; Kusters et al., 2018). Though many in form we take our definition from Kuster et al., (2018) who describe multi-stakeholder platforms as an initiative that convenes diverse actors to participate in a dialogue, set of decision making processes, and joint implementation arrangements, in order to address various objectives (Kuster et. al., 2018). In studying the Forum for the Complex we further adopted Kuster et al.'s formulation that a multi-stakeholder platform has certain characteristics that are also found at the Lake Complex, namely: it covers multiple goals drawn from multi-sectoral objectives; creates a space for multiple parties to convene and discuss the use and management of resources; is initiated by external parties, or a "bridging organization," such as NGOs and universities; and, the objectives are defined at the beginning but change over time as members continue to negotiate and discuss their interests (Kusters et al., 2018: 171). One characteristic specific to the Forum being that the community groups are assigned as the 'core members' of the forum, which point to another characteristic of a multi-stakeholder platform.

Aside from being integrative and polycentric, multi-stakeholder platforms are also political in nature. They advocate empowering the less powerful stakeholders through representation, encouraging the involvement of under-privileged and marginalized groups for various reasons, and compare them against that of 'business as usual' models that are normally sectoral, top-down, and expert-driven (Sarmiento et al., 2019). It also implicitly raises the differences between government and governance, whereby the former is a top-down, centralized, bureaucratic, and formal exercise of power and authority, whereas the latter is decentralized, informal, bottom-up, and is focused on responding to and serving public interests (Reed and Bruyneel, 2010: 647). Involving diverse parties at different levels, multi-stakeholder platforms with an integrated landscape approach present a type of governance that provide connections to government agencies, political representation of the people, and incorporates mechanisms for resource channeling (Garcia-Lopez, 2013). Such forums are also common among "integrated landscape approaches," which is understood here to be an initiative that convenes various stakeholders to work at a landscape scale in improving livelihoods, development, and conservation, while concomitantly introducing deliberate planning, management, and implementation practices through a participatory and collaborative learning framework (Estrada-Carmona, 2014; Kuster et al., 2017). Thus, multi-stakeholder platforms with an integrated landscape approach requires actors, sectors, and objectives to be brought together, to reconcile various land uses, replace "silos thinking" with an integrated perspective, addresses institutional conflicts that promotes synergies. Therefore it requires multiple and adaptive institutional arrangements and policy instruments (Bastos-Lima, 2017).

However, in terms of impacts, studies have found that multi-stakeholder forums for integrated landscape management initiatives may also present imbalances of power, whereby weaker parties receive less benefits (Garcia-Lopez, 2013), and rather improve implementation of existing policies by allocating additional financial resources rather than addressing structural land use issues or other underlying drivers of environmental degradation. Indeed, though the mechanism may promise procedural changes, it may in the end pursue business-as-usual, relegated to a 'niche approach' while limiting implementing to narrow environmental issues and ignoring its stated principles of collaboration (Bastos-Lima, 2017). A case in point by Ravikumar et al. (2014) found that unless the weaker parties were explicitly and boldly political about their interests, buttressed by political organizing to strengthen their bargaining positions, multi-stakeholder initiatives fail in both conservation and benefit to local people. This reflects what Reed and Bruyneel (2008) emphasize, namely that multi-stakeholder or polycentric governance does not mean the reduction in the power 
of the state, and rather, requires sufficient support from a democratic model of the state in order to fulfil its stated principles.

Studies of multi-stakeholder platforms emphasize various aspects, including participation and legitimation, the nature of relationships among stakeholders, planning and negotiation processes, and their relative outcomes (Kuster et. al. 2018). In this case study, we attempt to present multistakeholder platforms initiated from above and from below, highlighting the differences in the extent of participation and legitimation by delving into the processes through which the platforms were established, and furthermore, identifying the variety of stakeholders involved relative to their standing. In order to understand relative outcomes, we will present origins and the evolution of multi-stakeholder forums for integrated landscape management at the Lake Complex. Finally, by describing the factors that contributed to the current outcomes, we highlight the relationship between stakeholders within the platform. Though comprehensive, a complete analysis will have to wait for upcoming negotiation processes to unfold, as the main forum analyzed is still only two years old, and decisions regarding the main forum are still dynamic, evolving, and pending.

\subsection{Methods}

We gather the data from systematic reading of grey literature from three CSO projects on multistakeholder forums, including Wallacea, Univeritas Andi Djemma (UNANDA), and the Forum Pemerhati Kompleks Danau Malili (Forum for the Malili Lakes Complex, henceforth the Forum). The CSO project documents include interim and final reports, minutes of meetings, as well as maps produced during the project. The Forum documents comprised of principles, lists of activities (action plans), and draft of a district regulation (Rancangan Peraturan Daerah) formulated by the Forum. We conducted in-depth interviews with more than 20 representatives of the Forum. These key informants included representatives from government agencies (Spatial Planning and Housing Agency and Regional Planning Agency), NGOs (Wallacea and Yayasan Bumi Sawerigading), a local university (Faculty of Forestry at UNANDA), and community groups (Village Heads and Agroforestry Groups). We selected interviewees purposively, and thereafter applied a snow-ball technique to follow targeted data collection. We began by interviewing the initiator of the Forum, followed by NGO representatives, contacts from community and government agencies and more.

We also conducted observations in four villages around the Complex to learn about the landscapes and livelihoods issues that the were under consideration by the Forum. We also participated in one of the Forum meetings in the district capital. The fieldwork was carried out between March-April 2019 over two visits. However, this short period of data collection was also foregrounded by longstanding close relationships by one of the co-authors and his familiarity with local issues, having lived in Sorowako for more than two years, with long-established local contacts, and who understands key elements of the local social and political context. Given that we are examining the role of politics at scale and the impact of multi-stakeholder forums for integrated landscape management, we begin our results with an examination of the early initiatives to institute top-down forums, followed by a bottom initiative that received attention for its successes at collaboration, and complemented by an analysis of efforts to scale up the successful local initiative.

\section{Results}

\subsection{Top-Down Initiatives}

The Movement to Save the Lakes (GERMADAN, or Gerakan Penyelamatan Danau) was created during a meeting in 2009 that formed an agreement of nine national ministries to establish an integrated management approach to save the lake ecosystems. At the Complex, GERMADAN focused on protecting the lake through the framework of ecotourism. A task force (Pokja, or Kelompok kerja) for the Complex was established in 2014, with the Secretary of the District 
Government functioning as the ex-officio leader. They conducted a small-scale activity with very limited effects relative to the larger problems faced by the Complex. These included group cleanups of the lakes or fishing competitions to decrease populations of louhan (Amphilopus trimaculatus), one of the invasive exotic species to the lake. One member of GERMADAN reported that during the National Coordination Meeting held at the Lake (RAKORNAS DANAU) in March 2019, the Pokja was considered to be ineffective. The local informant expressed that GERMADAN only held high level discussions in exclusive locations, stating that "I was invited to some of the meetings in five-star hotels, but to date nothing seems to have happened beyond those meetings."

Another initiative that devoted specific attention to the Complex also emerged concurrently. The National Strategic Zone (KSN) was created through a regulation designed to conduct specialized attention on spatial planning for specific zones considered vital for Indonesia, which was established in 2008 under a Government Regulation (PP no. 26/2008). Sorowako and its adjacent areas were identified for its nickel and other mineral deposits, complementing the areas already under exploitation. According to the Law, the national government would conduct a special plan for use and management of such areas. However, since its establishment in 2008, there are yet to be any meaningful outcomes produced by the initiative. Another similar top-down initiative (KPPN, Kawasan Prioritas Penting Nasional [National Critical Priority Zones]) conducted a program that was considered to violate the national law on minimum distances for land use on lake riparian areas, and was scrapped for potentially degrading the lake. Through the district agricultural office, the initiative had invited a private company to open 250 ha for wet rice cultivation on the banks of Lake Mahalona.

Though designed to be collaborative, this latter case shows that top-down initiatives as this one overlooked the critical aspects of consulting with other stakeholders (in this case communities and CSOs), and their decisions clearly neglected the chains of decision making prior to implementation, which proposed an intervention that would potentially create negative effects to the local ecosystem. When the bottom-up collaborative Forum for the Lake Malili Complex emerged, and began to compile issues from communities around the lake, they highlighted the way that decisions were made from the top-down initiatives. These problems included a range of effects, from overlapping authorities governing landscapes, threatened endemic aquatic and terrestrial species and the increasing flock of invasive exotic fish into the lakes, increasing deposits of sedimentation and solid waste from home and industrial pollution, land conversion and deforestation for monoculture farming (in the form of a pepper rush caused by a spike in yield prices), to the lack of involvement of community in decision making processes, as well as the usage of the lake banks for different purposes that further deteriorate lake conditions. ${ }^{5}$ To date, none of the initiatives had taken an active role in addressing these problems.

The overall impacts of these top-down initiatives to protect species and habitats, and support local communities as per their mandate, pointed to the common issues associated with a lack of participation (Arnstein, 1969). This was particularly frustrating among local stakeholders given the mandates of empowering communities and restoring ecosystems. They provide no space for collective decision making and planning with local communities and/or NGOs, who only took part in tokenistic ways during program implementation. In this absence of accountability, we now shift to the traction that a bottom up initiative made in addressing some of these landscape scale considerations, which opened up opportunities to respond to and address, to a certain extent, local concerns.

\footnotetext{
${ }^{5}$ Report of Perkumpulan Wallacea, minutes of meeting of the Forum. Report from studies (TKTKTK)
} 


\subsection{The emergence of A Bottom-Up Program}

\subsubsection{The Forum for the Malili Lakes Complex}

A bottom-up initiative for participatory land use planning (PLUP) was conducted to fulfill political goals of recognizing community land rights. The Forum emerged from this initiative and began to gain attention at a local and national level. They produced key maps and documents that also helped to expand its function among the local stakeholders, and served as a space for colearning, conflict resolution, information sharing, and negotiation of shared activities.

The Forum applies a multi-stakeholder approach as an "integrated landscape initiative" (ILI) where different parties convened with diverse objectives, which includes various landscape components (i.e. agricultural fields, natural forest, fallows, lakes, rivers, and settlements), and are built around multi-stakeholder processes. The Forum assembles different stakeholders in order to "...integrate programs and activities in order to support integrative and sustained management of the Lake Complex." They invite relevant parties to work in coordination towards a vision of landscape conservation of the lake ecosystem in East Luwu. The Forum's main activities are (a) consultations or ad hoc meetings; (b) improving the organization and access of related knowledge and information; and (c) integration of plans with monitoring and evaluation efforts.

As a multi-stakeholder platform, the Forum's origins reflect bottom-up principles: a mix of conservation and equity considerations towards an overall objective of sustainable development, including: (a) biodiversity and landscape conservation, (b) peoples' welfare, (c) people as part of the subject of development, (d) respect for indigenous knowledge, (e) equal partnership among stakeholders, and (f) place the policymakers as regulators, facilitators, and catalyzers. The principles to place the people at the center of the Forum's objectives reflects a structure whereby the community groups (i.e. farmer and fisher groups, and village scale institutions) and village governments become the "core members," while other parties such as government offices and CSOs are listed as "related institutions" and "supporting institutions." The management board is also shared between government and community group representatives.

The forum originated from a series of grass roots activities. Established on November 9, 2017, the Forum was initiated by local Civil Society Organisations (CSOs), namely, Non-Government Organizations (NGOs) (Perkumpulan Wallacea, Yayasan Bumi Sawerigading, Lembar) and a local university (the Faculty of Forestry and Fisheries of UNANDA), together with community groups from four villages. Some support was provided by Burung Indonesia and the Critical Ecosystem Partnership Fund as part of their phasing out program. Programs were carried out by the CSOs in early 2016 and lasted through the end of 2018, involving several villages in two sub-districts: Nuha and Towuti, which are the only two sub-districts directly surrounding the banks of the five lakes within the Complex. The two sub-districts make up the Complex zone.

The local university began with research on threatened endemic species and their habitats, then proceeded to introduce, and create awareness about endemic trees, as well as providing training for community groups to rehabilitate endemic trees. Meanwhile, Perkumpulan Wallacea (an NGO) organized the communities to work around sustainable land use and participatory decision making processes. Their main agenda was to map areas around traditionally protected areas which were also the sites with the most endemic trees, as well as identifying organic farming initiatives that included agroforestry and breeding of trigona bees.

By working collaboratively the CSOs managed to firstly overcome the lack of trust from villagers. In the Village of Nuha and Matano, for instance, at the initial stage the university that had long conducted research in the area helped the NGO to gain trust from the community. Some informants in the village admitted that many of the community members had little trust working with NGOs at the outset, due to their previous experiences working with NGOs that come and go as their programs ended, often without the community benefitting from their engagements or 
resulting in promises unfulfilled. The emerging notion of trust and collaboration was further strengthened by the participatory mapping and land use planning initiative (entitled PLUP) carried out in collaboration with the NGOs.

These activities transferred technical skills and knowledge to local actors, helping to establish new networks and organization capabilities, as well as initiating more concerted local ownership over village level planning and policies. The NGOs introduced new skills to meet the policy moment of the village law, helping them to gain new resource allocations by providing greater knowledge to community groups that ranged from making organic fertilizer, mapping and use of GPS, and drafting land use plans and village regulations based on the results of participatory mapping. Furthermore, this engagement also helped to establish forest farmer groups that became the local institutions rersponsible for managing nurseries for endemic trees that have received training from the university representative. By identifying endemic species and habitats, the CSOs helped the community to discover that their village had rare and unique characteristics. which also helped communities to articulate local value in more specific terms, boosting their morale and helping them to see a future village of new possibilities, at once developing a greater appreciation of the surrounding environment.

The outcomes of these initial activities in the villages provided for the foundation for potential stakeholders to convene, preparing them to join together and co-found the Forum as an alliance at the district level. ${ }^{6}$ By the second year, the CSOs proceeded to conduct advocacy through multistakeholder meetings with the sub-district and district government, although interactions were mostly limited to sub-districts and district offices directly related to their advocacy (such as forestry, fishery, and the environment office). The Forum continued to follow up with a series of lower scale and stakeholder meetings, providing gtrainings and workshops. Within these activities, participants from the community and local government offices identified clusters of issues together, prepared the less empowered stakeholders with skills, knowledge, and documents (such as evidence-based land use plans), all of which were critical during negotiations at higher governing levels.

Among the motives for villagers to join the Forum were to advocate for their land rights, as many of their agricultural lands and settlements areas overlap with formal jurisdictions (such as "protected areas" [kawasan lindung] or land concessions). The outcomes of the PLUP initiative helped to identify land claims and allowed them to advocate for formal administrative releases of lands that they could prove to be theirs even though they were also delineated under "protected forest" (hutan lidung) designation. These lands had long been controlled as community land and the PLUP mapping helped them to identify these inconsistencies. By obtaining the release of these lands, local community members were able to reduce conflicts with formal authorities and establish more secure land tenure. Securing land rights in this way not only was empowering for local communities in the utilization of data for planning purposes, it also increased trust with formal institutions as their claims were also acknowledged. The data from the maps also came at a very political time, as it converged with the timing of a local election, and the issue also became a wedge issue for to convey populist ideals among candidates. The victorious politician in part won because of his promise to deliver the release of 70,000 hectares lands to local community control. However, prior to the mapping initiative, nobody was really sure where such lands were located. Therefore, the PLUP maps produced by the community helped to identify targeted locations.

According to one of the local NGOs that helped to facilitate the mapping, one of the original ideas to establish the Forum was to scale up advocacy for securing land rights. It was projected that establishing a forum at the district level, the forums across the four villages could eventually expand to all 28 villages within the two sub-regencies surrounding the lakes. Supported with a campaign

\footnotetext{
${ }^{6}$ The district level government is the key implementing level of government given the shift to a decentralized framework in the past two decades. The formalized levels of government include: national government, provincial (provinsi), district (kabupaten), sub-district (kecamatan), and village (desa).
} 
commitment by the elected head of the district to release protected areas back to community control, and making use of existing rules and resources from related agencies in the government, NGOs advocating for the Forum believed they had a better chance of supporting local community interests. Through higher level coordination these villages would also then be able to conduct similar PLUP initiatives, and thus be more prepared to advance the broader advocacy agenda of obtaining more secure land rights.

These hopes, at least at the outset seemed likely, as more than 20 village representatives arrived at the day the Forum was established. They also had a solid example of progress in bringing land rights aspirations to fruition based on previous activities, making use of existing institutions and rules. After participatory mapping in Nuha, a team from the Ministry of Environment and Forestry responsible for agrarian reform arrived in Sorowako. The village representative took the opportunity to show their map, including the land use plan that they had developed to demand their lands to be released from the protected area designation of the Ministry. The ministry team agreed to include them in the agrarian reform program, although to date the decision has not been formalized by the national government. This objective of advocacy for land rights also reflected in the election of the Forum secretary, the elected secretary is also a staff of the District Development Planning Board and responsible to synchronize maps within the district before it is submitted to the national one-map program (peta $B / G$ ).

However, as multi-stakeholder forums for integrated landscape governance is always political (Ravikumar et al. 2018), it is never a simple venue for advocacy. Once the Forum was established, more diverse interests and needs began to be raised, and a series of meetings and consultations ensued. Only by September 2018 had the forum identified their key issues and needs, finalizing a common vision, mission, principles, board structure, as well as an overall agenda. TABLE 1 shows the list of programs compiled by the Forum in 2018, whereby there were at least 37 programs and activities run or planned by no less than 21 institutions. By March 2019, the Forum formulated and agreed upon their "working components" (programs), which were determined to reflect the diverse interests and membership of the forum. These include the following: 1) ecosystem rehabilitation and protection, 2) institutional strengthening, 3) biodiversity conservation, 4) community empowerment, 5) ecotourism development (a detailed agenda is provided in TABLE 2).

\subsubsection{Scaling Up the Forum}

Forum initiatives began to gain more influence as evident from a series of campaigns and involvement in various activities. One of the first activities of the Forum was a campaign on environmental protection entitled The Malili Lake Complex Festival, 29 April - 2 May, 2018. The Festival comprised of a tour to clean up the 3 large Lakes, distribute endemic tree seeds, environmental photography coaching, a seminar on ecosystem protection of the Lake Complex, and a roundtable discussion on the development of business from non-timber forest products. Gaining greater visibility, one notable example of the Forum was their invitation to attend the National Coordination Meeting for Managing Indonesia's Lakes (RAKORNAS DANAU) in Jakarta. During the meeting, district government representatives, who did not have a design for integrated management of the lakes, requested the Forum to represent them to showcase their management framework. The presentation was well received and of the 15 lake regions invited from across Indonesia, they were the only group that had an integrated management forum. Furthermore, another province in attendance was also inspired to follow the same model of establishing a forum. Upon return to the district, the Forum also gained attention from others across the Complex to join the forum. Even some of the top-down entities - like CSR programs of PT Vale - became interested in participating in the forum.

Hence, the Forum has worked to formulate a draft of a District Head Regulation (Peraturan Bupati) on collaborative management of the Complex. The regulation would potentially widen the 
scope of the Forum, providing them with a sustained stream of annual funding support, and would by law strengthen its position in managing the Complex to ensure more stakeholder participation. It required more than a year to finalize the draft, which involved intensive advocacy by Forum members to fulfill each of the complex legal steps. Though the draft is complete, until the time of writing, the regulation has yet to be signed and enacted.

Despite these efforts, supported by increased visibility, and seemingly expanded mandate, active participation among stakeholders, especially throughout villages within the Complex, has begun to improve and the function of the Forum is expanding. First, the Forum has become a space for information sharing, which helps to serve various ends. The ability to share information across stakeholders as part of a formal gathering helped not only to provide regular updates on new programs and issues that arose in the Complex, but furthermore the gathering also helped to facilitate actions between government programs with relevant communities. One example includes the information about new rice fields expanding on the banks of Mahalona Lake. Project implementation resulted from these regular meetings, in which the Forum leader was able to recommend to BPDAS (the River Basin Protection Office) and KPH Larona (Forest Management Office) to direct their tree nursery and planting projects to the village forums in order to support forest farmer groups. Secondly, the Forum also served as a co-learning space. In a meeting with the Forum and the BKSDA, KPH Larona, and community groups, the offices had a space to learn about how to better communicate their activities with a broader range of audiences, and were also able to align their initiatives more closely with local aspirations. The communities themselves were also able to understand more about the terms and rules of government institutions. For example, during a Forum discussion the attending village government representatives learned that the village governments would not violate any rules when using Village Budgets for participatory mapping activities. This is important because of compliance requirements for local decision-making processes. Third, the forum also provided a space for limited conflict resolution. For instance, the Forum facilitated numerous discussions on the village boundary between the Village of Soroako and Tole, and they were successful in mediating a follow up plan with the government office responsible for village boundaries (also a Forum member) that was in attendance.

Fourth, the Forum also serves as a space to negotiate collaborative work. For example, when the Forum asked BKSDA and the KPH to conduct collaborative patrols around protected areas, they agreed to do so with the community members on the north bank of Lake Matano. The proposal for joint patrols emerged from attempts at land conversion by people coming from outside of certain villages and encroaching on protected areas. Encroachers mention the names of top officials or local strongmen when confronted by local villagers, in which case, the villagers would usually back off. Another alternative solution has been proposed to address this problem. Proposed by community representatives, a formal letter would be issued for villagers to act as 'community rangers,' because the formal official rangers rarely come to the protected areas. 7 This proposal was accepted at the meeting but until the time of writing, actions from this have not yet materialized.

Finally, the Forum serves as a mediating space for weaker stakeholders to solve problems that were not directly related to the agenda, but otherwise could not be solved on their own. The farmer group of Nuha village, for example, faced a problem with a government contract where they were assigned to provide seedlings for a planting program, in which they would potentially receive less than what they had anticipated. The leader of the Forum, with his strong network and influence in district bureaucracy, stepped in and the problem was solved with some phone calls. ${ }^{8}$

\footnotetext{
7 Interview with Head of Agroforestry Group of Nuha Village (April 2019).

${ }^{8}$ The Forum leader currently serves as one of the head of the district office, but he is also known as a "forest defender." He is the former head of the district's forestry office and was strict in tracking down illegal logging, but fair in terms of confronting anyone violating rules (even towards local strongmen or high officials). He also has a long history of engagement with environmental NGOs, openly collaborating in community forestry programs in the past. He is also writing a PhD thesis on the impact of land use on the lake within the Complex.
} 


\section{Discussion}

We have presented three empirical sections in this paper, describing top down initiatives to bring groups together to address joint concerns of the Complex, followed by the emergence of a bottom-up network among a group of villages, and finally, described how successes from the bottom up processes gained broader momentum and were institutionalized as part of a more regional multistakeholder Forum. The top-down initiatives to implement integrative landscape approaches at the Complex reflected a continuation of business-as-usual, in which "government" bureaucratic means were prioritized over "governance" measures that various stakeholders held direct interests in addressing. The centralized systems of the top-down measures rarely materialized into mechanisms for addressing concerns among stakeholders interested in conservation and development.

Meanwhile, the early manifestations of the Forum shows that a bottom-up initiative to meaningfully address local concerns can provide a foundation for establishing mechanisms for collaborative learning, sharing, and advocacy. The bottom-up initiative shows how engaged grassroots activities that build trust among NGO programming that listens to and responds to local concerns can complement an agenda that can become power given the right political conditions. This was clearly on display during the PLUP activities, which saw the mapping processes for making claims to land translate into real advocacy as it coincided with a local populist election campaign to support villages to make claims to land. As this campaign succeeded, the available data and the strong relationships made from the mapping processes and partnerships at the local level became a convenient setting for demanding accountability.

As this local collaboration mechanism was established and reshaped into a more formalized Forum that involved a larger network of groups, it coincided with additional visibility from the national lakes meeting. Having collected the data and conducted planning processes, the local government turned to the Forum to showcase their plan. This led to notable acknowledgement by other lakes regions and national government agencies, which in turn translated into additional momentum for the Forum.

Although several initiatives have emerged since these events, the timing of this analysis points to the fact that it still remains to be seen to what extent the Forum's initiatives will be institutionalized. The Forum has tried to establish a formal district head regulation to provide it a stronger mandate. The Forum continues to work with local communities to try to establish community patrols for unlawful encroachment of land, supports programs to rehabilitate endemic species through the Forum, and overall, has seen an increase in more meaningful gatherings to coordinate stakeholder interests. Furthermore, the Forum seems to also command a convening role to more powerful interests, including government agencies and other actors seeking to implement programs at various locations with villages and connecting to project implementer (like farmer groups). Even the mining company PT Vale, has agreed to participate with the Forum by involving their CSR representatives.

As the Forum has sought to scale up their efforts and establish its functions, our analysis has shown that the Forum has become an entity that works better on, and prioritizes certain aspects. For the time being, the Forum works better on partial and incidental elements such as convening stakeholders, limited conflict resolution and negotiation between a few parties, conducting broad public interest campaigns, and works less towards overtly vertical political lobbying, such as working to influence and produce legally binding documents. The grassroots precursors of the Forum that helped it gain traction among local communities revolved around commitments to advocate for local rights to land. As the Forum has become a more formal regional entity, increasingly higher level representatives from various stakeholders are privileged to speak on a broader range of topics, that are coincidentally less political, and less responsive to local concerns. Indeed, far limited results have been achieved from those that initially sought out potentially longer-term transformative changes, such as the critical dimension of advocacy for land rights. Rather than actively advocate for political 
outcomes such as land rights as before, the Forum mechanism can now only wait for decisions to come from above.

Across each of the stages of these multi-stakeholder efforts we observe several notable trends, all of which relate to the importance of being political. In the initial stages of top-down coordination, stakeholder groups can be characterized for the broader complacence and distrust for addressing issues of common concern around the Complex. The grassroots initiative is notable in this respect, for being able to strategically and overtly act politically during a particular political moment. They developed mechanisms for accountability that converged with the arrival of a populist political messaging campaign in local elections. The Forum was thereafter propelled in national conservation and development forums, gaining attention, support, and praise by national powerful actors. The Forum thus gained prominence throughout the Complex, attracting previously reluctant stakeholders to get involved. In trying to scale up the Forum to have a broader influence throughout the communities along the lakes, they tried to accommodate a growing number of voices. As the Forum expanded to accommodate its expanding functions, however, new challenges emerged about who ultimately would be able to decide outcomes to pursue.

The Forum thus gained a newfound legitimacy, and conducted activities to play a convening and facilitation role, which has led to a change in decision making processes and a shift in the allocation of resources. Nevertheless, our analysis also shows the stagnation and the limitations of this current manifestation of the Forum. Ongoing attempts at formalization, the voices raised amidst the Forum's meetings, and the type of initiatives it supports has shifted to an approach of much less overtly political interests. In this way, the Forum has begun to stagnate in terms of what might once have been possible with its rise. It is thus either looking for its next political moment, or has transformed into an entity that will be limited in its potential for responding to the concerns that led to its initial rise to prominence.

This poses some important lessons for multi-stakeholder forums on integrated landscape management. Barletti and Larson (2019) have argued that better coordination cannot stand alone to achieve the larger objectives of equitable and sustainable land use. In fact, more degradation and unequal land use can be produced by better coordination of stakeholders who benefit from such results. The Forum, though successful at establishing itself, is now particularly at risk if its longerterm functions begin to reflect the more top down and less accountable approaches that were in place before it was created. The Forum originated from grassroots groups at a village level, consisting of local people with actual interests about their lands and landscapes. These initial forums at the village level enabled the previously lesser heard stakeholders to formulate and assert relevant issues into key development agendas identified by the communities themselves. They used participatory mapping and the power of information on both land use and endemic and endangered species to advocate for outcomes. These efforts allowed the communities to raise evidence-based issues at the Forum, and crucially supported the voices of the less powerful stakeholders to be actively engaged. They were also well positioned in key instances of political moments, which propelled their legitimacy into new opportunities. Nevertheless, the future benchmark for the Forum, and other multi-stakeholder forums more broadly, will be gauged on the extent to which it engages with, can influence, and will be influenced by politics.

\section{Acknowledgments}

The research was supported by the Critical Ecosystem Partnership Fund (CEPF) through Burung Indonesia. However, this paper solely represents the researchers view, and not necessarily those of CEPF. The writing process was assisted by Forest and Society, and the review and feedback has been very valuable in developing the ideas for this article.

\section{Conflicts of interest}

The authors declare no conflict of interest. 


\section{Appendices}

Table 1. Activities and Responsible Institutions around the Lake Malili Complex

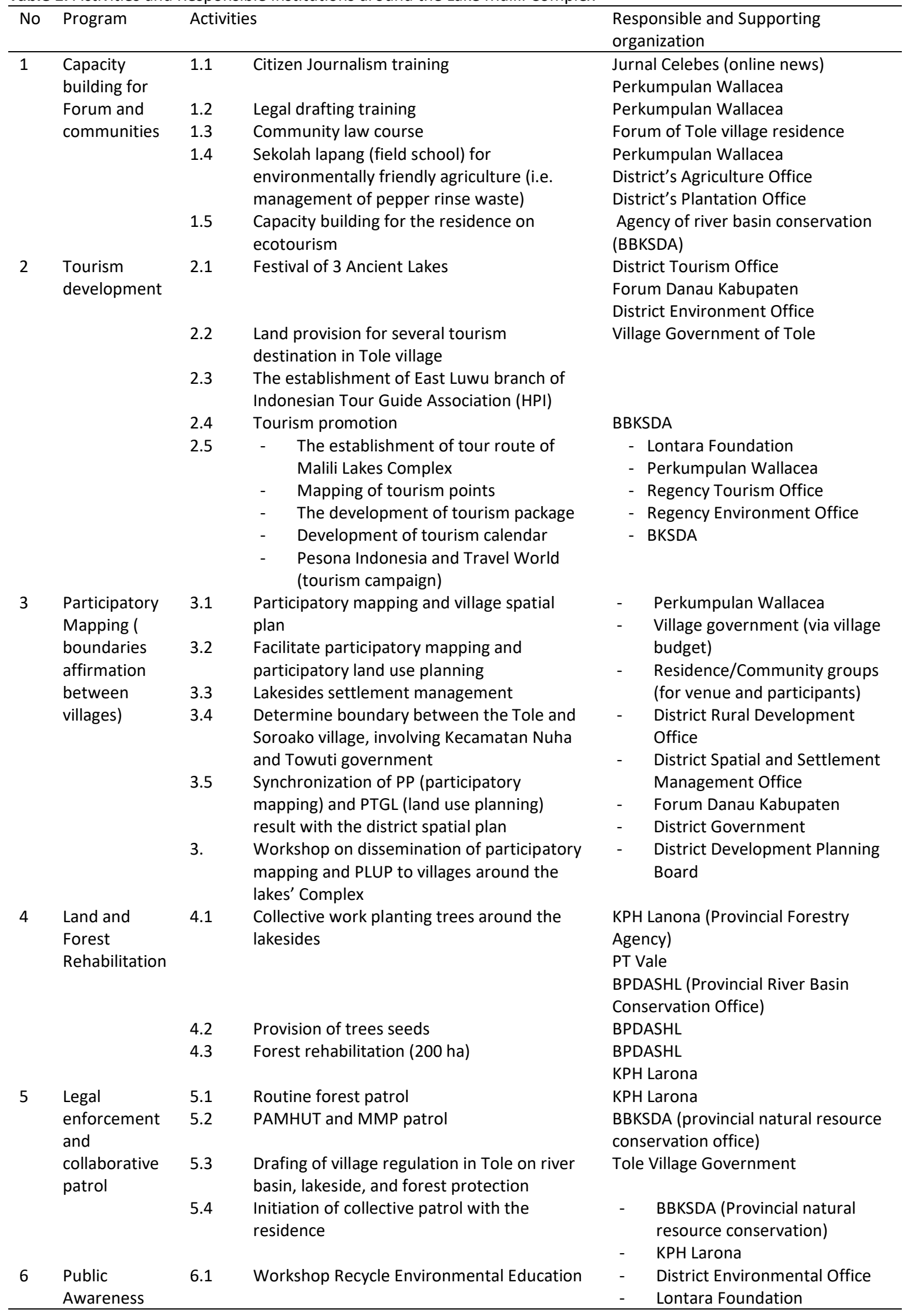




\begin{tabular}{|c|c|c|c|c|}
\hline & $\begin{array}{l}\text { Rising } \\
\text { Campaign }\end{array}$ & & $\begin{array}{l}\text { Garbage market/recycle craft Environmental } \\
\text { education in schools }\end{array}$ & \\
\hline & & 6.2 & Cleaning river and lakes program & District Environment Office \\
\hline & & 6.3 & Provision for plastic garbage recycle & Village Governments \\
\hline & & 6.4 & Campaign for saving 'the last forest' & $\begin{array}{ll}\text { - } & \text { Walhi South Sulawesi } \\
\text { - } & \text { Perkumpulan Wallacea }\end{array}$ \\
\hline & & 6.5 & Campaign for saving protected faunas & $\begin{array}{ll}- & \text { BBKSDA } \\
\text { - } & \text { Burung Indonesia }\end{array}$ \\
\hline & & 6.6 & $\begin{array}{l}\text { Publication on the Forum activities via social } \\
\text { media and online news }\end{array}$ & $\begin{array}{ll}\text { - } & \text { Perkumpulan Wallacea } \\
\text { - } & \text { Jurnal Celebes } \\
\text { - } & \text { District Government PR }\end{array}$ \\
\hline & & 6.7 & $\begin{array}{l}\text { Environmental campaign to avoid to put } \\
\text { living (exotic) fishes to the lake }\end{array}$ & \\
\hline 7 & Database & 7.1 & Workshop on Lake tourism model and MoU & BBKDAS \\
\hline & & & $\begin{array}{l}\text { between the District Government with } \\
\text { Environment and Forestry Ministry on Lake } \\
\text { Ecotourism Park }\end{array}$ & $\begin{array}{l}\text { - } \quad \text { FKKM (community forestry } \\
\text { communication forum) }\end{array}$ \\
\hline & & 7.2 & Partnership between residence and PT Vale & - $\quad$ FKKM \\
\hline & & & & $\begin{array}{l}\text { - } \quad \text { Forum Pemerhati Kompleks } \\
\text { Danau Malili }\end{array}$ \\
\hline & & 7.3 & Research Center on Ancient Lakes and & Baperlitbangda (District \\
\hline & & & Biodiversity & Development Planning Board) \\
\hline & & 7.4 & Dissemination of agroforestry & - $\quad \mathrm{KPH}$ Larona \\
\hline & & & & $\begin{array}{l}\text { - } \quad \text { Faculty of Forestry, Universitas } \\
\text { Andi Djemma (UNANDA) }\end{array}$ \\
\hline & & 7.5 & Database on endemic fishes in Towuti Lake & - $\quad$ Faculty of Fishery, UNANDA \\
\hline & & & & - $\quad$ District Development Planning \\
\hline & & 7.6 & Database on endemic ecosystem in Towuti & Board \\
\hline & & & Lake & $-\quad$ IUCN \\
\hline & & 7.7 & $\begin{array}{l}\text { Updating status of endemic species in } \\
\text { Mahalona Lake }\end{array}$ & \\
\hline
\end{tabular}

Table 2. The Forum Component and sub-component (as of March 2019)

\begin{tabular}{|c|c|c|}
\hline No & Components & Components \\
\hline 1 & $\begin{array}{l}\text { Ecosystem rehabilitation and } \\
\text { protection }\end{array}$ & $\begin{array}{l}\text { - } \quad \text { land use planning and mapping } \\
\text { - } \quad \text { forest and land rehabilitation, land and water conservation } \\
\text { - } \quad \text { rezoning forest bloc and Eco-tourism Park (TWA) } \\
\text { - } \quad \text { reducing the rate of lake sedimentation } \\
\text { - } \quad \text { knowledge management } \\
\text { - } \quad \text { illegal fishing and logging monitoring and forest patrol }\end{array}$ \\
\hline 2 & Institutional strengthening & $\begin{array}{l}\text { - strengthening Forum Pemerhati Kompleks Danau Malili as a space } \\
\text { to accelerate the establishment similar Forums in village level } \\
\text { community capacity building in program planning, } \\
\text { implementation, monitoring and evaluation for institutional } \\
\text { development and sustainable funding }\end{array}$ \\
\hline 3 & Biodiversity conservation & $\begin{array}{l}\text { - } \quad \text { research on lake species } \\
\text { - } \quad \text { research on endemic flora and fauna } \\
\text { - } \quad \text { invasive species control }\end{array}$ \\
\hline 4 & Community empowerment & $\begin{array}{l}\text { - } \quad \text { garbage management } \\
\text { - } \quad \text { development of organic and environmentally friendly farming } \\
\text { - } \quad \text { development and dissemination of agroforestry system } \\
\text { - } \quad \text { dissemination of sustainable fishing } \\
\text { - } \quad \text { strengthen Forest Farmer Group (KTH) and Lake Concern Group at } \\
\text { village level }\end{array}$ \\
\hline 5 & Ecotourism development & - Malili Lake Complex festival \\
\hline
\end{tabular}


- $\quad$ Establishment of tourism point in Lake Mahalona, Matano, and Towuti.

- $\quad$ National workshop (among researchers working on Lake Malili Complex) sarasehan nasional (peneliti di kompleks danau Malili)

Table 3. Identified Problems and Needs of the Forum

\begin{tabular}{|c|c|}
\hline Problems according to Forum (18 Sept 2018) & Needs \\
\hline $\begin{array}{ll}\text { - } & \text { destructive fishing } \\
\text { - } & \text { introduction of new invasive species } \\
\text { - } & \text { palm oil estate by the lake } \\
\text { - } & \text { pollution } \\
\text { - } & \text { illegal land deals } \\
\text { - } & \text { unclear boundaries of PT Vale concession } \\
\text { - } & \text { abrasion and sedimentation } \\
\text { - } & \text { muddy lake water } \\
\text { - } & \text { forest and land degradation } \\
\text { - } & \text { unclear boundaries between villages } \\
\text { - } & \text { forest conversion for pepper } \\
\text { - } & \text { unclear areas assigned as the lake banks }\end{array}$ & $\begin{array}{l}\text { - } \quad \text { Legality of Forum from local government } \\
\text { - } \quad \text { Planning for biosphere protection } \\
\text { - } \quad \text { Review of 'core' protected block under KPH } \\
\text { - } \quad \text { Larona to become 'empowerment' block } \\
\text { - } \quad \text { Design for multi-stakeholder lake management } \\
\text { - } \quad \text { District level regulation on the lake landscape } \\
\text { - } \quad \text { management } \\
\text { - } \quad \text { (social forestry) and TORA (agrarian reform) } \\
\text { - } \quad \text { Monitoring/patrol the water catchment areas } \\
\text { and the lakes. }\end{array}$ \\
\hline
\end{tabular}

\section{References}

Bastos-Lima, M. G., Visseren-Hamakers, I. J., Braña-Varela, J., \& Gupta, A. (2017). A reality check on the landscape approach to REDD+: Lessons from Latin America. Forest Policy and Economics, 78, 10-20. doi: https://doi.org/10.1016/j.forpol.2016.12.013

Burung Indonesia. (2014). "Ecosystem Profile: Wallacea Biodiverisity Hotspots." Unpublished Report.

Estrada-Carmona, N., Hart, A. K., DeClerck, F. A., Harvey, C. A., \& Milder, J. C. (2014). Integrated landscape management for agriculture, rural livelihoods, and ecosystem conservation: An assessment of experience from Latin America and the Caribbean. Landscape and Urban Planning, 129, 1-11. doi: https://doi.org/10.1016/j.landurbplan.2014.05.001

García-López, G. (2013). Scaling up from the grassroots and the top down: The impacts of multi-level governance on community forestry in Durango, Mexico. International Journal of the Commons, 7(2). doi: http://doi.org/10.18352/ijc.437

Köhne, M. (2014). Multi-stakeholder initiative governance as assemblage: Roundtable on Sustainable Palm Oil as a political resource in land conflicts related to oil palm plantations. Agriculture and human values, 31(3), 469-480. doi: https://doi.org/10.1007/s10460-014-9507-5

Kusters, K., Buck, L., de Graaf, M., Minang, P., van Oosten, C., \& Zagt, R. (2018). Participatory planning, monitoring and evaluation of multi-stakeholder platforms in integrated landscape initiatives. Environmental management, 62(1), 170-181. doi: https://link.springer.com/article/10.1007/s00267-017-0847-y

Myers, R., Larson, A. M., Ravikumar, A., Kowler, L. F., Yang, A., \& Trench, T. (2018). Messiness of forest governance: How technical approaches suppress politics in REDD+ and conservation projects. Global Environmental Change, 50, 314-324. doi: https://doi.org/10.1016/j.gloenvcha.2018.02.015

National Geographic Indonesia. (2008). Edition November.

Palopopos, "PT Vale suntik Rp282 M ke Pemda", 17 July 2019.

Ravikumar, A., Larson, A. M., Myers, R., \& Trench, T. (2018). Inter-sectoral and multilevel coordination alone do not reduce deforestation and advance environmental justice: Why bold contestation works when collaboration fails. Environment and Planning C: Politics and Space, 36(8), 1437-1457. doi: https://doi.org/10.1177/2399654418794025 
Reed, M. G., \& Bruyneel, S. (2010). Rescaling environmental governance, rethinking the state: A three-dimensional review. Progress in human geography, 34(5), 646-653. doi: https://doi.org/10.1177/0309132509354836

Reed, M. S., Graves, A., Dandy, N., Posthumus, H., Hubacek, K., Morris, J., ... \& Stringer, L. C. (2009). Who's in and why? A typology of stakeholder analysis methods for natural resource management. Journal of environmental management,90(5), 1933-1949. doi: https://doi.org/10.1016/j.jenvman.2009.01.001

Riggs, R. A., Langston, J. D., Margules, C., Boedhihartono, A. K., Lim, H. S., Sari, D. A., ... \& Sayer, J. (2018). Governance challenges in an Eastern Indonesian forest landscape. Sustainability, 10(1), 169. doi: https://doi.org/10.3390/su10010169

Sahide, M. A. K., \& Giessen, L. (2015). The fragmented land use administration in IndonesiaAnalysing bureaucratic responsibilities influencing tropical rainforest transformation systems. Land Use Policy, 43, 96-110. doi: https://doi.org/10.1016/j.landusepol.2014.11.005

Sarmiento Barletti, J.P., and Larson A.M. (2019). "The role of multi-stakeholder forums in subnational jurisdiction." Occasional Paper 194. CIFOR

Sayer, J., Margules, C., Boedhihartono, A.K, Dale, A., Sunderland, T., Supriatna, J., Saryanthi, R. (2014). "Landscape approaches: what are pre-conditions for success?" Sustain Sci. doi: https://doi.org/10.1007/s11625-014-0281-5 .

Shohibuddin, M., Cahyono, E., \& Bahri, A. D. Undang-Undang Desa dan Isu Sumberdaya Alam: Peluang Akses atau Ancaman Eksklusi?. Wacana: Jurnal Transformasi Sosial, 17, 36.

Ostrom, E. (2010). Beyond markets and states: polycentric governance of complex economic systems. American economic review, 100(3), 641-72. doi:

https://doi.org/10.1257/aer.100.3.641 